(C2019, Elsevier. Licensed under the Creative Commons Attribution-NonCommercialNoDerivatives 4.0 International http://creativecommons.org/about/downloads 


\title{
Evaluating the effect of organizational architecture in developing science and technology parks under differing innovation environments.
}

\author{
Mousa Al-kfairy, Souheil Khaddaj and Robert B. Mellor. \\ Computing and Maths, Kingston University, London, UK
}

Corresponding author: r.mellor@Kingston.ac.uk

Abstract:

Science and Technology Parks (STPs) are often used as tools to foster regional development. They seek innovations, innovators and encourage innovation amongst the constituent firms, including by networking and knowledge spill over between the inhabitants, Universities and sources of capital. The low success rate of STPs led us to investigate how STP architecture can best cope with a changing and challenging innovation environment, through start-up to early maturity and full maturity, in a preliminary effort to arrive at an evidence-based scheme to help avoid failure.

Three different types of architecture were investigated: open (market), star (hierarchy), and closed strong (adhocracy, ambidextrous). Open (market) architecture suffered both from high transaction costs while not protecting against poor decision-making. Results show that it is very beneficial to have a central Cluster Initiative $(\mathrm{Cl})$ controlling the decision-making process (star, hierarchy) in the early stages of STP development, where potential gains and losses are relatively modest. However in the early maturity stage with commitment to a high-growth trajectory, a high quality of decision-making is required amongst managers and decisions are best taken by the $\mathrm{Cl}$ with the input of optimally two individual on-cluster firms. The situation where $\mathrm{Cl}$ is supported by goodquality decisions from on-cluster firms - an ad hoc, ambidextrous situation - is superior when good innovations abound and the STP has acquired some maturity. However, in environments with a surfeit of poor-fit innovations, this becomes a high-risk strategy with high potential losses and indeed in this situation, retaining a hierarchical ( $\mathrm{Cl}$ only) decision process is most helpful, even when the quality of decision-making amongst $\mathrm{Cl}$ managers is poor. Results indicate that success involves attracting enough small innovative firms which - in turn - attract larger firms, whose detailed sector-relevant insight improves $\mathrm{Cl}$ decision-making.

Keywords. Innovation; organizational architecture; Monte Carlo; Science and Technology Park; Structural Equation Modelling (SEM)

\section{Introduction}

One way in which governments and local authorities seek to enhance regional development is through support for business clusters, a high-tech form of which is the Science and Technology Park (STP). Although there is no general agreement on the definition of business clusters (Zhao et al., 2009) the International Association of Science Parks and Areas of Innovation (IASP) define STPs as "... an 
organisation managed by specialised professionals, whose main aim is to increase the wealth of its community by promoting the culture of innovation and the competitiveness of its associated businesses and knowledge-based institutions" and that "The expressions "technology park", "technopole", "research park" and "science park" encompass a broad concept and are interchangeable within this definition" (IASP, 2016). A broader definition is by Porter who regards them as a set of interconnected firms working in close proximity and related industries that are connected to a reputable Higher Education Institute (HEI) and Venture Capital (VC) and sometimes supported by local authorities (Porter, 1998; Porter, 2000).

The STP is a popular tool, indeed IASP reports that they have more than 344 members in 77 countries (IASP, 2016), while in Europe alone there are more than 365 STPs with more than 750,000 employees (Rowe, 2014). Expenditure can be considerable e.g. Wallsten (2004a) and Wallsten (2004b) reported that in 1999 Hong Kong invested 2 billion US dollars in building an STP.

Unfortunately, there is a high failure rate for STPs (Wadhwa, 2013). The World Bank, report success rates of around $20 \%$ and a rate of abject failure of around $20 \%$, both figures globally (Kelly and Firestone, 2016), while in Wales 60\% failed recently (Pugh et al., 2018). Ernst and Young (2017, p19) states that for the $f 2.2 \mathrm{bn}$ UK Catapult programme, "...it is unlikely that the impact of the network overall has been significant ...", however these authors do also point towards the importance of highquality of decision-making in an environment containing many risky innovations "Catapults that had a chairperson with relevant business and industry experience ... performed relatively more strongly ..." Ernst and Young $(2017, \mathrm{p} 17)$

The research presented here investigates why many expensive failures occur while some STPs grow and succeed. Recent reviews recount the factors which have been considered as success factors for STPs, see e.g. Cojocaru and lonescu (2016) as well as Diez-Vial and Fernández-Olmos (2017) and results from panel data studies showing that in a successful mature STP, the corporate performance of on-cluster firms (here referred to as " $F$ ") is highly and positively correlated to total social expenditure i.e. investing in social networking (Al-Kfairy et al., 2017; Al-Kfairy et al., 2018), a finding that supports earlier work indicating that tacit innovation strongly affects product and development innovation (Casanueva et al., 2013), and problem solving (Mellor, 2003; Mellor, 2011). Clearly, state actors may establish large parks (a "top-down" approach) where the role of the $\mathrm{Cl}$ is largely the collection of rent from tenants, but here we are concerned with small start-up STPs developing around a science theme ("bottom-up").

To change perspective from the point of view of the inhabitants, to the view of the STP itself, it is clear that the STP is created and then develops over time. Within any given period, some inhabitants will leave and, within the parameters that STP has (for example, the amount of space available), new inhabitants will be selected. Indeed, in order to avoid technology "lock-in", STPs must have a continual influx of new innovations (i.e. innovative firms), which it turns demands that new inhabitants are chosen that are in harmony with, and can enhance, the direction of the whole STP (Al-kfairy et al 2019a). For STPs to be successful, it has been argued that they must attract and select the most suitable and innovative firms to reside on the park. Indeed, Chen et al. (2006) concluded that selecting suitable tenants to inhabit the Park is crucial to create a successful STP. Furthermore, because the central Cluster Initiative $(\mathrm{Cl})$ performs the selection, makes all decisions and implements them, the quality of $\mathrm{Cl}$ management team is positively related to STP performance (Albahari, 2015; Albahari et al. 2016).

Researchers including Will et al. (2019) emphasise that innovations are not all positive and that especially in environments seeking innovations, that costly negative "bad" innovations abound (Mellor, 2019). At its most simple, then where the benefit of a "good" innovation is I and the costs to achieve it are $C$, then the net gain is $I-C$. Where an innovation is unsuitable for whatever reason, then the net loss is larger, namely; $-(I+C)($ Mellor, 2019) implying that STPs need a constant positive-sum 
game just to survive. How this is achieved is a research gap (see e.g. Lönnqvist and Laihonen, 2017). Because most studies on STPs evaluate them using financial or quantities indicators (Klofsten et al., 2015) with very little attention being paid about how STPs are organised and operate. Nonetheless, it is important to analyse which organizational architectures may be superior regarding selecting good projects (as addressed in the literature on the ambidextrous organization (Benner and Tushman, 2003; Benner and Tushman, 2015; and O'Reilly III and Tushman, 2013), because it is the organizational architecture of the corporation that defines how risky decisions are made and implemented (Sah and Stiglitz, 1985; as well as Sah and Stiglitz, 1986), thus it is the organizational architecture that determines outcomes for organizational performance.

Organizational architectures are conduits for networks; in STPs participation in networking activities has been shown to promote knowledge sharing among inhabitants (Koçak and Can, 2014) and indeed Al-kfairy et al. (2019b) found that networking (measured as social expenditure) was highly correlated with good performance in a mature STP. Models provided by Al-kfairy et al. (2019a) showed that in the initial stages of a nascent STP, the "star" architecture is most efficient, where all firms inhabiting the STP have one connection to the $\mathrm{Cl}$ and no other connections, because this architecture is very economical on transaction costs. Later in STP development a "strongly connected model" may develop where some firms may liaise intensively together and with the $\mathrm{Cl}$ (Al-kfairy et al., 2019a). Structural equation modelling (SEM) analysis showed that the potential rewards from this model can be very large, concomitantly however the risks of significant losses are also extremely high (Al-kfairy et al., 2019a).

The importance of a central $\mathrm{Cl}$ in STPs is widely acknowledged; this is the executive instance of the organisation that manages the STP helping on-cluster firms to grow (e.g. Díez-Vial and MontoroSánchez, 2016) via e.g. providing a set of activities, support policies and selecting new inhabitants. In environments where positive innovations abound the decision-making capacity of the $\mathrm{Cl}$ and the organizational architectures assume low importance. Conversely, STPs may be erected in geographical localities that have too few positive potential inhabitants to sustain it, and thus have to accept inhabitants that are poor fits ${ }^{1}$ for the STP which in turn leads to the rapid failure of the whole venture. In intermediate situations the ability of the $\mathrm{Cl}$, the decision-making process and the STP organizational architecture will in the long run determine success or failure.

STP communication and transaction costs were categorized by lammarino and McCann (2006) into informal channels (e.g. social networking) where transaction costs are minimized by "trust" between organizations, which in turn, requires complementarities leading to long-term relationships. It is tempting to speculate that failure to correctly manage this tipping-point transition could also contribute to success or failure of the STP. The new Innovation Based View (Mellor, 2015) finally allows SEM analyses to be made at various stages of STP development and therefore differing organizational architectures have been investigated (Markusen, 1996; Cowan et al., 2007) and Monte Carlo methods (Davis et al., 2007; Chib and Greenberg, 1996; Robinson, 2014) used to investigate potential gains for an STP under (a) differing conditions of quality of managerial decision-making and (b) in environments containing different proportions of beneficial innovations.

\section{Methodology}

Monte-Carlo simulations (Chib and Greenberg, 1996) were performed in Matlab 2018R. Throughout it is assumed that managers choose innovations blindly from an initial portfolio of innovations containing projects with "negative" as well as "positive" consequences for organizational

\footnotetext{
${ }^{1}$ From the Innovation Based View (see Mellor, 2015) inhabitants, potential or on-cluster, can be referred to as "innovations" because this view regards the innovative new firm as a mere vehicle for an innovation.
} 
performance, because they always a priori assume that their innovation will have positive consequences for corporate performance independently of whether this ex post is true or not, or otherwise, that they can distinguish the quality of the innovation and make a "correct" decision. Further assumptions are that "incoming innovation" is encapsulated in a business vehicle i.e. the manager either adds, or not, a new innovative firm (F) to the on-cluster group of firm, and that (in the case of closed network) only two $\mathrm{F}$ firms assist the $\mathrm{Cl}$ in decision making, because although many $\mathrm{F}$ firms are available, including more will always over-proportionally increase the transaction costs.

Different decision-making methods were simulated based on the organizational architectures using a Cellular Automata approach (Davis et al., 2007), similar to studies published previously (Alkfairy et al., 2019a; Will et al., 2019; Mellor, 2014a). Simulations were performed when organisational architecture is based on one of the following:

Table 1: Overview of the architectures investigated.

\begin{tabular}{|l|l|}
\hline Number & The architecture tested \\
\hline 1 & $\begin{array}{l}\text { Open network ("market structure") where firms are loosely connected to each other } \\
\text { and each firm can invite other firms into the cluster based on their own judgment. } \\
\text { This represents a control case to compare with other STP cases, because it violates } \\
\text { the most accepted definitions of STPs, but it can form a useful baseline, as shown in } \\
\text { Section 2.1, (equations 1 - 3, figures 4 - 5). }\end{array}$ \\
\hline 2 & $\begin{array}{l}\text { Start-up structure ("star architecture") where all firms are connected to one } \mathrm{Cl} \text { and } \\
\text { decisions are made unilaterally by the Cl. This situation also represents a baseline } \\
\text { control and is shortly illustrated in section 2.2, (equations } 4 \text { and 6, figure 6). }\end{array}$ \\
\hline 3 & $\begin{array}{l}\text { Start-up structure ("star architecture") where all firms are connected to one } \mathrm{Cl} \text { and } \\
\text { decisions are made by the firms and the Cl collaboratively (Cl and Firms, section 2.2, } \\
\text { equations 4 - 7, figures 7 and 8). }\end{array}$ \\
\hline 4 & $\begin{array}{l}\text { Closed network (adhocracy, a strongly-connected model, section 2.3), this is } \\
\text { represented by any two firms jointly making a decision without involving the Cl } \\
\text { (equations } 8-10, \text { figures } 11 \text { and 12). }\end{array}$ \\
\hline 5 & $\begin{array}{l}\text { The ambidextrous organisation, operating within a strongly-connected model, } \\
\text { where a joint decision is made by any two firms and then the Cl (equations } 9 \text { and 11, } \\
\text { figures 9 and 10) in section 2.3. }\end{array}$ \\
\hline
\end{tabular}

For each of the above, the quality of the decision-making at managerial level was varied between:

a. Managers make decisions randomly i.e. 50:50, as in flipping a coin.

b. Managers always make the right decision.

c. Managers can make decisions with a random degree of accuracy between $50 \%$ and $100 \%$. (The case of managers making decisions with between $0 \%$ and $50 \%$ accuracy was omitted from this work because this could be a situation for e.g. state institutions, but not for STPs).

Throughout the simulation, the following vectors were randomly generated:

a. The number of firms in a cluster was randomly generated from uniform distribution between 6 and 500 , and stored in the variable $(n)$, which helps to control for cluster size effects.

b. A vector of innovation $\mathrm{MU}$ outcome (I-C) was generated from a uniform distribution with a net innovation value of between -1000 and $1000 \mathrm{MU}$ for each firm (f) and stored in the 
vector Innovi, where (i) represents the firm index between 1 and $(n)$, and $(n)$ changes for each simulation run.

c. Then, we generate a single $\mathrm{Cl}$ quality value from a uniform distribution, where the $\mathrm{Cl}$ quality values changes only for each simulation run. The value was selected to be between 0 and 1 and stored in $\left(q_{c}\right)$.

d. After that we generated a number of vectors from a uniform distribution representing the quality of firms managers $\left(q_{f}, i\right)$, random decisions of firms $\left(d_{i}\right)$, and random decision of $\mathrm{Cl}$ as $\left(C I_{i}\right)$, where $(i)$ is from 1 to $(n)$, and each value is between 0 and 1 . The same vectors were used foreach of the different simulated architectures to ensure the consistency of the simulation results.

e. The cost of innovation was generated between 0 and 100 from a uniform distribution and was stored in the vector $\left(T C_{i}\right)$, where $(i)$ is from 1 to $(n)$.

The simulation was run 5000 times to ensure the production of robust results.

The different situations were used at aggregate level, which reflects the overall innovation at cluster level because of the assumption that cluster innovation is the total of the innovation of the firms inhabiting the STP. Thus, STP success is the total net benefit gained by all actors. The different types of innovations were evaluated using equations $(1-11)$ in sections 2.1 - 2.3.

\subsection{Open Network Business Cluster Structure (market architecture)}

In this case (table 1, number 1), the STP includes a number of firms, which are not connected to each other, and each firm implements its innovation independently of $\mathrm{Cl}$ or other firms. Then, the quality of management decisions is simulated with the parameter $\left(q_{m}, i\right)$, where for $\mathrm{F}$ managers it is between ( 0.5 and 1.0) and randomly generated from uniform distribution, so that if $\left(q_{m, i}<0.75\right)$ indicates that a manager with a medium quality of decision, who most likely makes 50:50 random decisions (as in flipping a coin). Otherwise, they are of a very high quality and will make the right decision (i.e. accepting good innovations and rejecting bad innovations). A vector of $(n)$ element was then generated representing all managers in on-cluster firm level (F1, F2, etc), where each manager is different from any other in both decision-making capabilities, and the cash value of innovations generated. Random decisions are simulated with the value $\left(d_{i}\right)$ which is between $(0-1)$ generated from uniform distribution and indicates that if $\left(d_{i}>0.5\right)$ meaning a positive decision and accepting the innovation regardless of the actual outcome (positive or negative). For each run, a new number of firms $(n)$ is generated, which enables us to control for the role of cluster size.

Using open network architecture, the following cases were simulated:

i. On-cluster firms implement an innovation independently of $\mathrm{Cl}$ and of any managers, so any incoming project can be implemented. This case is implemented as a control experiments for comparison purposes with other cases. So, no quality checks are done in this case, and no control for random decisions. In this case, the net innovation cash flow for all firms $(b)$ is calculated using equation 1 , where $\operatorname{Innov}_{i}=I_{i}-C_{i}$ and $I_{i}$ is the innovation outcome cash value, and $C_{i}$ is the cost of implementing that innovation:

$\mathrm{b}=\sum_{\mathrm{i}=1}^{\mathrm{n}} \operatorname{Innov}_{\mathrm{i}}$

$\mathrm{b}$ is the net total innovation, $\operatorname{Innov}_{\mathrm{i}}$ is the incoming innovation project value for firm (i)

ii. The managers of on-cluster firms decide. If they have good decision-making skills $\left(q_{f, i}>\right.$ $0.75)$ - where $q_{f, i}$ is the quality of the decision making for firm at index (i) - then they only 
implement good innovations $\left(\left(\right.\right.$ Innov $\left.\left._{i}-T C_{i}\right)>0\right), T C_{i}$ is the decision making cost (transaction cost), otherwise the innovation is rejected (see equation 2 ):

$$
b=\left\{\begin{array}{c}
\left.\sum_{i=1}^{n} \text { Innov }_{i}-T C_{i}, \text { if }\left(q_{f, i}>0.75\right) \text { and }\left(\text { Innov }_{i}-T C_{i}\right)>0\right) \text { or }\left(d_{i}>0.5\right) \\
\left.b-T C_{i}, \text { if }\left(q_{f, i}>0.75\right) \text { and }\left(\text { innov }_{i}-T C_{i}\right)<0\right) \operatorname{or}\left(d_{i}\right)
\end{array}\right.
$$

iii. Then, the quality of decisions made is not checked, meaning that $\mathrm{F}$ managers will only approve if $\left(d_{i}>0.5\right)$ regardless of the value of the innovation (random decisions). This is summarised in the equation 3 :

$$
b=\left\{\begin{array}{c}
\sum_{i=1}^{n} \text { Innov }_{i}-T C_{i}, \text { if }\left(d_{i}>0.5\right) \\
b-T C_{i}, \text { if }\left(d_{i}<0.5\right)
\end{array}\right.
$$

\subsection{Start-up Structure (star architecture)}

In this case, STP firms are connected to the central organisation called Cluster Initiative ( $\mathrm{Cl})$, which act as control agency helping firms connecting with VCs and build internal relationships as well as coordinating activities and innovations. The baseline control (table 1, number 2 ) assumes a stable functioning steady-state STP scouting for innovations examines 100 innovations each worth 100 Monetary Units (MU) and in this case the costs for implementing a decision are fixed for the purposes of illustration to $20 \mathrm{MU}$ and the decision-making costs to $2 \mathrm{MU}$. Table 2 is a simple illustration and briefly shows that even with $100 \%$ dependable decision-making by $\mathrm{Cl}$ managers, the returns are dependent on the quality of the innovations presented to that STP.

Table 2: Returns from 100 innovations each worth $100 \mathrm{MU}$ where the innovations are of varying quality and presented to a $\mathrm{Cl}$ management with $100 \%$ correct decision-making ability.

\begin{tabular}{|l|l|}
\hline Percent of "good" innovations & Return (MU) \\
\hline 100 & 7800 \\
\hline 50 & 3800 \\
\hline 0 & -200 \\
\hline
\end{tabular}

Moving to the case of table 1 , number 3 , the mean (average) quality of the $\mathrm{F}$ decision-makers checking the innovation must be greater than the cut-off point $(0.75)\left(\mu\left(q_{m, i}, q_{f}, i, \ldots\right)>0.75\right)$ and this figure is reached because at this point two good quality $\mathrm{F}$ managers can overcome the poor decision of a third F one. However, this cannot happen without cost (e.g. discussion times), which is in this simulation is obtained randomly for each firm (from a uniform distribution) with a value of $(0 \leq$ $\left.T C_{i} \leq 100\right)$, and the value of a beneficial innovation value is simulated with $\left(-1000 \leq\right.$ Innov $_{i} \leq$ $1000) \mathrm{MU}$, meaning that an innovation with the value $\left(\operatorname{Innov}_{i} \leq 0\right)$ is a poor innovation.

In contrast, the decision-making quality at $\mathrm{Cl}$ level was given a random constant quality because, as shown in figure 1 , the quality of $\mathrm{Cl}$ decisions applies to all other on-cluster firms indiscriminately (i.e. it does not change according to the number of firms in the STP) with the value $\left(0.5 \leq q_{c} \leq 1\right)$, and $\left(q_{c}\right)$ is the quality of the $\mathrm{Cl}$ managerial decision making, so each time an innovation has to be 
considered this can change between $\left(0 \leq C I_{i} \leq 1\right)$ where $\left(C I_{i}<0.5\right)$ indicates a probable rejection (regardless of whether the outcome would have been positive or negative). Figure 1 shows the science park organisation, where each firm is connected to the central organisation $\mathrm{Cl}$, in a star architecture reflecting the state-centred cluster organisation.

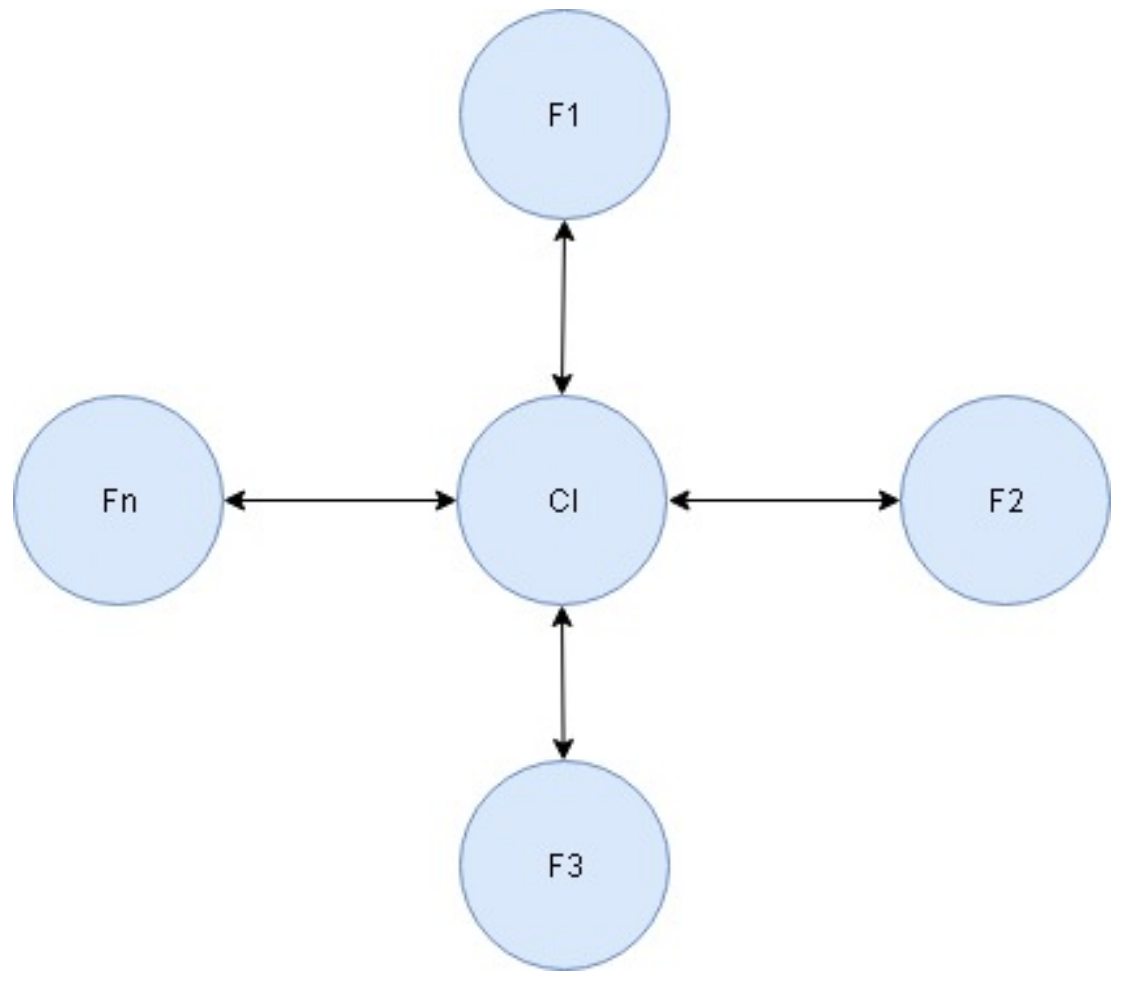

Figure 1 Science Park Organisation (star architecture)

Using organizational architecture as in figure 1, there are four different situations for types of decision-making:

i. Similar to table 1, number2, incoming innovations are evaluated by $\mathrm{Cl}$, and a decision depends on the decision-making quality within the $\mathrm{Cl}$, so if quality high $\left(q_{c}>0.75\right)$ the innovation will be implemented if $\left(\left(\operatorname{Innov}_{i}-T C_{i}\right)>0\right)$ resulting in a positive cash flow, otherwise, the innovation is not approved. On the other hand, if $\mathrm{Cl}$ managers are of average quality, then the innovation will be if $\left(\mathrm{CI}_{i}>0.5\right)$, where $\mathrm{Cl}_{i}$ represents a random decision made by $\mathrm{Cl}$ management. See equation 4 :

$\mathrm{b}=\left\{\begin{array}{c}\left.\sum_{\mathrm{i}=1}^{\mathrm{n}} \operatorname{Innov}_{\mathrm{i}}-\mathrm{TC}_{\mathrm{i}}, \text { if }\left(\mathrm{q}_{\mathrm{c}}>0.75\right) \text { and }\left(\operatorname{Innov}_{\mathrm{i}}-\mathrm{TC}_{\mathrm{i}}\right)>0\right) \text { or }\left(\mathrm{CI}_{\mathrm{i}}>0.5\right) \\ \mathrm{b}-\mathrm{TC}_{\mathrm{i}}, \text { if }\left(\mathrm{q}_{\mathrm{c}}>0.75 \text { and }\left(\text { innov }_{\mathrm{i}}-\mathrm{TC}_{\mathrm{i}}\right)<0\right) \text { or }\left(\mathrm{CI}_{\mathrm{i}} \leq 0.5\right)\end{array}\right.$

ii. Incoming innovations are evaluated by both the F manager of the on-cluster firm responsible as well as the $\mathrm{Cl}$. In the first case star architecture structure is taken, and the quality of the decision is calculated as the mean of both managers quality, meaning firstly that if the mean quality is below the cut-off point, then an approval of both managers must be obtained, which in turn involves doubling the transaction costs, as given in the following equation 5 :

$$
b=\left\{\begin{array}{c}
\sum_{i=1}^{n} \text { Innov }_{i}-2 \times T C_{i}, i f\left(\mu\left(q_{c}, q_{f, i}\right)>0.75 \text { and }\left(\text { Innov }_{i}-2 \times T C_{i}\right)>0\right) \text { or }\left(\left(d_{i}>0.5\right) \text { and }\left(C I_{i}>0.5\right)\right) \\
b-2 \times T C_{i}, \text { if }\left(\mu\left(q_{c}, q_{f}, i\right)>0.75 \text { and }\left(\text { innov }_{i}-2 \times T C_{i}\right)<0\right) \text { or }\left(\left(d_{i}<0.5\right) \text { or }\left(C I_{i}<0.5\right)\right)
\end{array}\right.
$$


iii. In the third case, there will be no quality checks. Consequently, implementing any innovation projects approval is done by the $\mathrm{Cl}$, and depends on the approval value of the $\mathrm{Cl}$, if $\left(C I_{i}>0.5\right)$, then the innovation will be implemented. Otherwise, it will be rejected. It is assumed that the decision will change between different firms over time. This is summarised in the following equation 6 :

$$
b=\left\{\begin{array}{c}
\sum_{i=1}^{n} \operatorname{Innov}_{i}-T C_{i}, \quad \text { if }\left(C I_{i}>0.5\right) \\
b-T C_{i}, \text { if }\left(C I_{i}<0.5\right)
\end{array}\right.
$$

iv. In the last case, the check is done by both the $\mathrm{F}$ managers and $\mathrm{Cl}$ managers. However, the approval of both managers must be obtained. On the other hand, the transaction cost will be doubled as it needs checking from two managers, and even if the second check would take less time, but two managers will still be involved. This is simulated using the following equation 7:

$$
b=\left\{\begin{array}{c}
\sum_{i=1}^{n} \text { Innov }_{i}-2 \times T C_{i}, \text { if }\left(\left(d_{i}>0.5\right) \text { and }\left(C I_{i}>0.5\right)\right) \\
b-2 \times T C_{i}, \text { if }\left(\left(d_{i}<0.5\right) \text { or }\left(C I_{i}<0.5\right)\right)
\end{array}\right.
$$

Next, the different decision-making process situations applied when having a strongly connected STP architecture are discussed

\subsection{Closed Network (Strongly connected: Adhocracy and Ambidextrous)}

In the third case, the cluster organizational architecture modelled consisted of a closed network (strongly-connected model) organisation where the decision will be discussed between two oncluster firms making decisions (table 1, number 4) or two on-cluster firms with the $\mathrm{Cl}$ (table 1, number 5 ), illustrated in figure 2 . The simulations involved: 


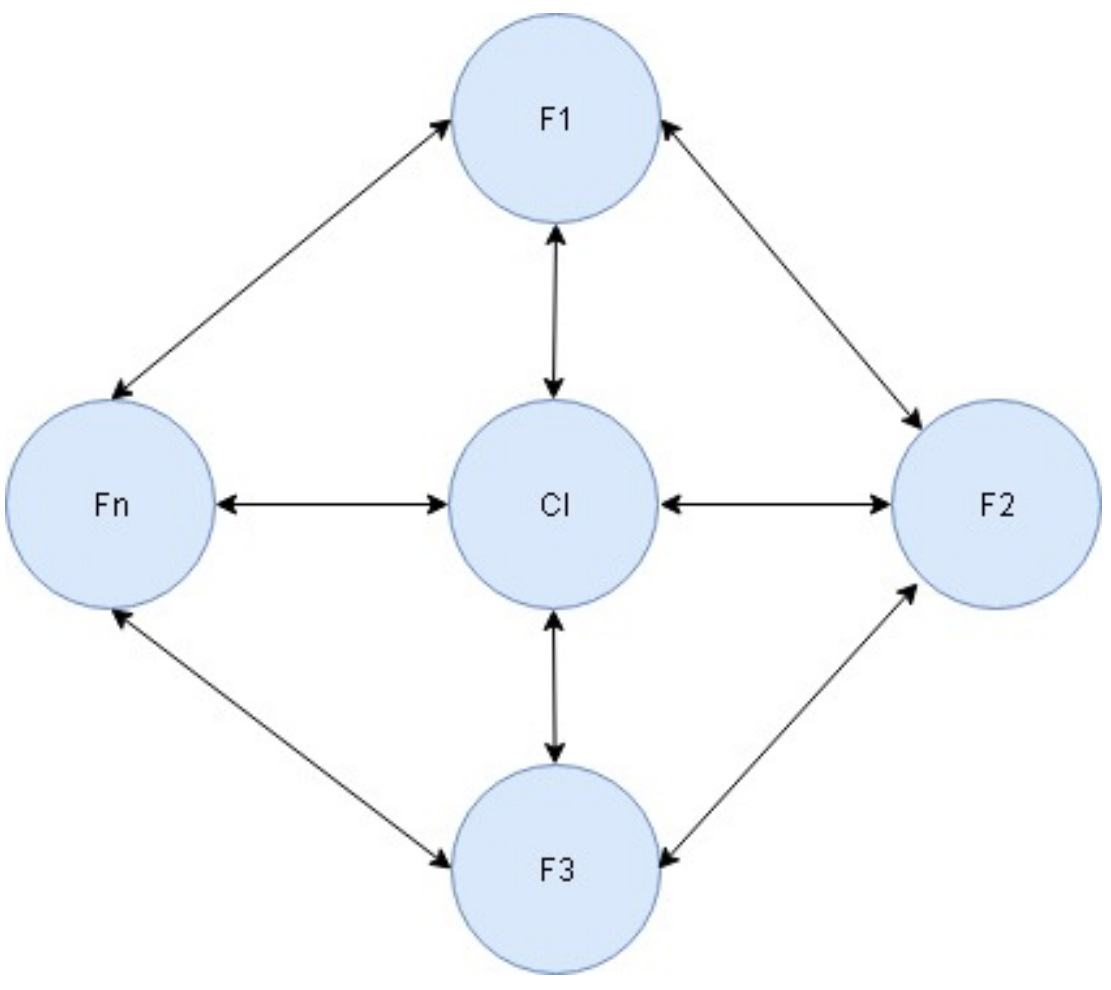

Figure 2 Strongly-connected with $\mathrm{Cl}$

i. In the first case, the decision is discussed between the two F managers at F1, and F2 collaboratively (Figure 2). Similar to previous cases, the quality of both $\mathrm{F}$ managers is the mean quality of both $\mathrm{F}$ managers, and if that exceeds the cut-off point, then they will make the right decision. Otherwise, introducing the innovation will need both managers approval. This is simulated using the following equation 8 :

$b=\left\{\begin{array}{c}\sum_{i=1}^{n} \text { Innov }_{i}-2 \times T C_{i}, i f\left(\mu\left(q_{f, i}, q_{f, i}\right)>0.75 \text { and }\left(\text { Innov }_{i}-2 \times T C_{i}\right)>0\right) \text { or }\left(\left(d_{i}>0.5\right) \text { and }\left(d_{j}>0.5\right)\right) \\ b-2 \times T C_{i}, \text { if }\left(\mu\left(q_{f, i}, q_{f, i}\right)>0.75 \text { and }\left(\text { innov }_{c i}-2 \times T C_{i}\right)<0\right) \text { or }\left(\left(d_{i}<0.5\right) \text { or }\left(d_{j}>0.5\right)\right)\end{array}\right.$

ii. The second case controls if the $\mathrm{Cl}$ is involved in the decision-making process. In that case the quality of the decision will be the mean of the three decisionmakers. We chose the mean of the three managers quality in order to obtain comparable results and thus be consistent throughout the simulation. Otherwise, the decision is approved if it gets approved by the three managers. Of course, the check cost (transaction cost) will be different from other cases, however, the assumption is that it will be triple the actual check cost. This is more of a tree hierarchal structure. This case was modelled using the following equation 9 :

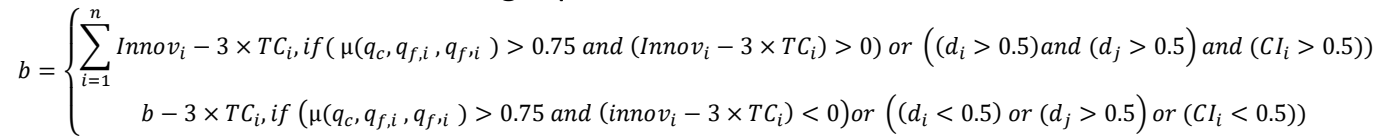

iii. The same cases were then simulated, but without looking into the quality of the decision makers, assuming that decisions are made randomly, which enables us to distinguish between having high quality decision makers and 
coin-flipper decision makers in a hierarchal cluster model. Thus, when the decision is discussed between the two F managers at F1, and F2 (Figure 2). Similar to previous cases, to introduce in innovation will need both managers approval. This is simulated using the following equation 10 :

$b=\left\{\begin{array}{c}\sum_{i=1}^{n} \text { Innov }_{i}-2 \times T C_{i}, \text { if }\left(\left(d_{i}>0.5\right) \text { and }\left(d_{j}>0.5\right)\right) \\ b-2 \times T C_{i}, \text { if }\left(\left(d_{i}<0.5\right) \text { or }\left(d_{j}>0.5\right)\right)\end{array}\right.$

iv. Then, it controls if the $\mathrm{Cl}$ is involved in the decision-making process. In that case the decision is approved if it is accepted by the three managers. Then, the check cost will be triple the actual check cost. This case is modelled using equation 11.

$$
b=\left\{\begin{array}{c}
\sum_{i=1}^{n} \text { Innov }_{i}-3 \times T C_{i}, \text { if }\left(\left(d_{i}>0.5\right) \text { and }\left(d_{j}>0.5\right) \text { and }\left(C I_{i}>0.5\right)\right) \\
b-3 \times T C_{i}, \text { if }\left(\left(d_{i}<0.5\right) \text { or }\left(d_{j}<0.5\right) \text { or }\left(C I_{i}<0.5\right)\right)
\end{array}\right.
$$

\section{Results}

\subsection{Open Network "Market" architecture}

The results presented in Table 3, number 1, illustrate perhaps unsurprisingly that in this case, the best outcomes occur when high-quality decisions are made by firm (F) managers, while random decisions give rise to outcomes that are not as favourable, although the best-case situations do not show significant differences between firms with high-quality $\mathrm{F}$ managers and firms which implement any upcoming innovation. Correlation analysis on the quality of decisions showed a moderate correlation of around 0.110 and p-value of less than 0.001. Thus, the size (number of firms) and the average innovation income from project initiatives (table 3) were compared and found that the size of the cluster does not have any correlation when there is no control at all, not even random $50 \%$. However, it does positively impact overall levels of innovation when $\mathrm{F}$ managers exhibit high decisionmaking quality and is negative when $\mathrm{F}$ managers are coin flippers (50:50 outcomes). Table 3 shows the number of simulation iterations $(\mathrm{N})$ and indicates that in the extreme worst case (min values), random decisions are almost as bad as implementing any incoming innovation in the open market situation. However, in best case situation (no check) is almost double that of the random decision case, confirming that random decision-making is good when incoming innovations are poor, but random reduces the total final innovation outcome when innovations are beneficial.

Figures 3,4 and 5 show the relationship between the number of firms in a cluster and the net innovation income, showing the random relationship between cluster size and net innovation in the absence of quality control (figure 3), while it is negative when decisions are random (figure 5), and positive when quality checks are available (figure 4). Furthermore, table 4 illustrates that average innovation income is the main determinant when there is no quality check, while both the number of firms, as well as the quality of managers, are both positively correlated with the net innovation income when innovations are checked at firm level. On the other hand, the number of firms negatively impact the net innovation income when decisions are made randomly, which in turn has a negative effect on cluster scalability. These results highlight that if an STP accepts any incoming innovation, then the main determinant is the average innovation cash value. But because it is not possible to have good innovations all the time, the implication is that this this unstructured "market" architecture should be avoided. 
Table 3 Descriptive Statistics of Different Decision-Making Configuration

\begin{tabular}{|l|c|c|c|c|c|}
\hline \multirow{2}{*}{ Decision making procedure } & N & Min & Max & Mean & STD \\
\hline No Check & $5,000.00$ & $-40,798.00$ & $40,180.00$ & 47.42 & $9,251.95$ \\
\hline Check by Firm(with quality control) & $5,000.00$ & $-13,014.00$ & $53,329.00$ & $9,608.89$ & $9,455.28$ \\
\hline Random Decision by Firm & $5,000.00$ & $-46,945.00$ & $23,537.00$ & $-6,268.25$ & $8,536.72$ \\
\hline
\end{tabular}

$\mathrm{N}$ is number of simulation iteration, Min is the minimum net innovation measured as $\mathrm{MU}$, Max is the maximum net innovation measured as $\mathrm{MU}$, and mean is the mean net innovation measured as $\mathrm{MU}$

Table 4 Pearson Correlation (Open Network architecture)

\begin{tabular}{|l|l|l|l|}
\hline & $\begin{array}{l}\text { No } \\
\text { Check }\end{array}$ & $\begin{array}{l}\text { Check by } \\
\text { Firm(with } \\
\text { quality } \\
\text { control) }\end{array}$ & $\begin{array}{l}\text { Random } \\
\text { Decision } \\
\text { by Firm }\end{array}$ \\
\hline $\begin{array}{l}\text { Average } \\
\text { Innovation }\end{array}$ & $0.656^{* *}$ & $0.322^{* *}$ & $0.349^{* *}$ \\
\hline NOF & 0.007 & $0.579^{* *}$ & $-0.408^{* *}$ \\
\hline
\end{tabular}

** statistically significant at $99 \%$, NOF is Number of Firms 


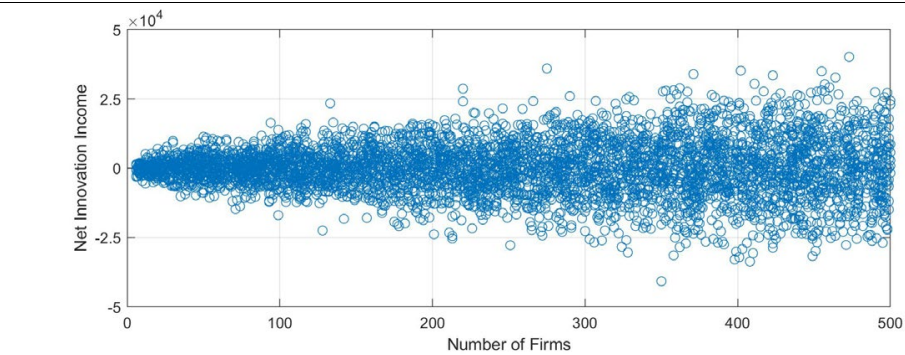

Figure 3: Open Network, firms implementing any incoming innovation VS the number of firms inside the business cluster (equation 1).

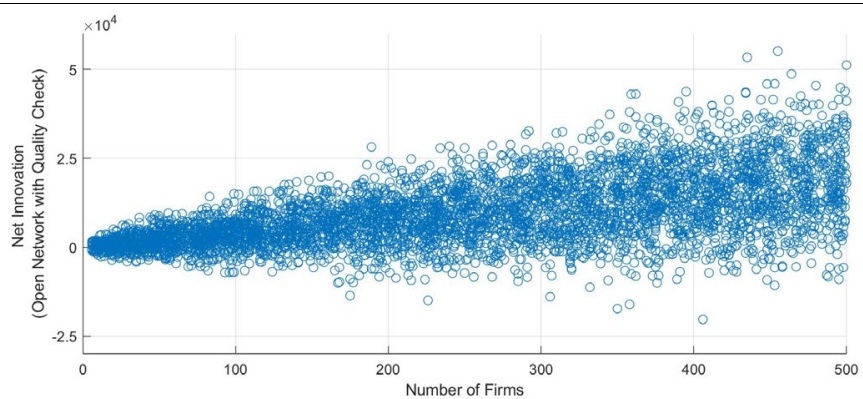

Figure 4: Open Network, Firms implementing incoming innovation based on Firms Managers Quality and Value of the Incoming innovation VS number of firms inside the business cluster (equation 2).

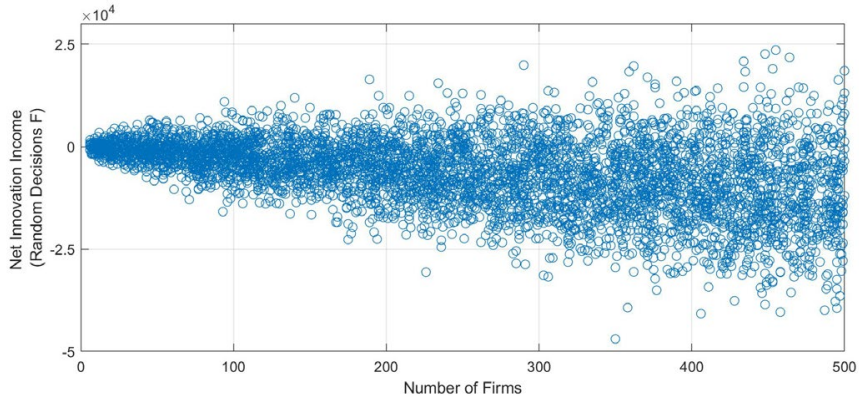

Figure 5: Open Network, Firms implementing incoming innovation based on a random decision made by firms manager VS number of firms inside the business cluster (equation 3).

\subsection{Start-up Structure (star architecture)}

This section deals with the situations in table 1, numbers 2 and 3, i.e. a "star" start-up structure when a $\mathrm{Cl}$ is involved. The different cases investigated are:

i. Decisions are made by $\mathrm{Cl}$, and $\mathrm{Cl}$ quality is checked.

ii. Random decisions are made by $\mathrm{Cl}$ management.

iii. Collaborative decisions are made by $\mathrm{Cl}$ and $\mathrm{F}$ management with quality checks.

iv. Random collaborative decisions by $\mathrm{Cl}$ and $\mathrm{F}$ management.

Table 5 Descriptive Statistics Star architecture

\begin{tabular}{|l|l|l|l|l|l|}
\hline & N & Min & Max & Mean & STD \\
\hline Check by Cl (with quality control) & $5,000.00$ & $-41,352.00$ & $129,583.00$ & $9,839,03$ & $33,080.00$ \\
\hline
\end{tabular}




\begin{tabular}{|l|l|l|l|l|l|}
\hline Check by Cl and Firm (with quality control) & $5,000.00$ & $-58,022.00$ & $63,431.00$ & $-4,435.28$ & $15,575.27$ \\
\hline Random Decision by Cl & $5,000.00$ & $-41,352.00$ & $25,242.00$ & $-6,239.06$ & $8,535.59$ \\
\hline Random Decision by Cl and Firm & $5,000.00$ & $-64,590.00$ & $16,571.00$ & $-12,529.71$ & $11,940.63$ \\
\hline
\end{tabular}

$\mathrm{N}$ is number of simulation iteration, Min is the minimum net innovation measured as MU, Max is the maximum net innovation measured as MU, and mean is the mean net innovation measured as $M U$

Table 5 presents descriptive statistics of star architecture structure showing that in the worstcase, all decisions making situations are - almost - equivalent. This is because in an environment with many negative innovations even coin-flipping managers avoid expensive mistakes to almost the same extent as discriminating managers do. Best-case occurs when $\mathrm{Cl}$ managers have a high quality and decide alone, the reason being that collaboration between $\mathrm{Cl}$ managers and $\mathrm{F}$ managers (which is also good) also doubles the transaction costs, thus detracting from the final value.

In order to understand the impact of different factors in each of the decision-making situations, the correlation analysis was controlled between average firms' innovation, average check cost, number of firms and the final net innovation values obtained (table 6).

Table 6 Correlation Analysis Star architecture and Average Innovation,

Check Cost, and Number of Firms

\begin{tabular}{|l|l|l|l|}
\hline & $\begin{array}{c}\text { Average } \\
\text { Innovation }\end{array}$ & $\begin{array}{c}\text { Average } \\
\text { Check } \\
\text { Cost }\end{array}$ & $\begin{array}{c}\text { NOF: } \\
\text { Number } \\
\text { of Firms }\end{array}$ \\
\hline $\begin{array}{l}\text { Check by Cl (with } \\
\text { quality control) }\end{array}$ & $0.075^{* *}$ & $-0.130^{* *}$ & $0.146^{* *}$ \\
\hline $\begin{array}{l}\text { Check by Cl and } \\
\text { control) }\end{array}$ & $0.110^{* *}$ & $-0.476^{* *}$ & $-0.184^{* *}$ \\
\hline $\begin{array}{l}\text { Random Decision } \\
\text { by Cl }\end{array}$ & $0.362^{* *}$ & $-0.417^{* *}$ & $-0.422^{* *}$ \\
\hline $\begin{array}{l}\text { Random Decision } \\
\text { by Cl and Firm }\end{array}$ & $0.144^{* *}$ & $-0.600^{* *}$ & $-0.599^{* *}$ \\
\hline
\end{tabular}

** Statistically significant at $99 \%$

Table 6 shows that in case of random decisions, net innovation is mainly impacted by the number of firms (negatively), average firms' innovation (positive), and check cost (negative). However, in case of decision making with quality check, these factors had mainly moderate to low impact (figures 6-8), and the impact of managerial decision-making on net innovation (in the case of quality check), shows a very strong correlation (the net total innovation 0.744 and the quality of $\mathrm{Cl}$ managers 0.633 ), indicating that a major role is played by qualified managers, a finding apparently confirmed when increasing the number of firms (thus also increasing the number of managers). However when 
comparing decision-making by the $\mathrm{Cl}$ only and by the $\mathrm{Cl}$ and F-managers in the star architecture (where firms communicate over the $\mathrm{Cl}$ ), any positive effect is counteracted by the increased transaction costs; table 6 showing a low negative value. This underlines that in start-up conditions (as well as under conditions of negative innovation environment) the hierarchical star architecture is always most efficient (Al-kfairy et al, 2019a).

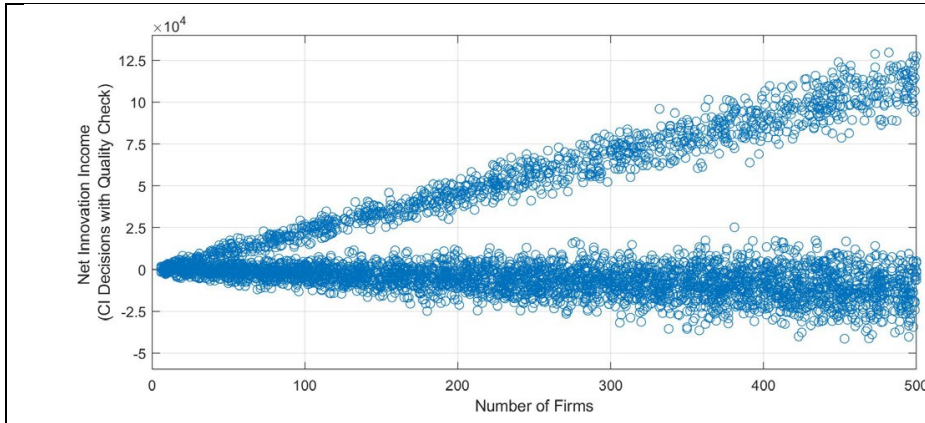

Figure 6: Star architecture, firms implementing incoming innovation based on the $\mathrm{Cl}$ managers quality of decisions making VS number of firms (equation 4).

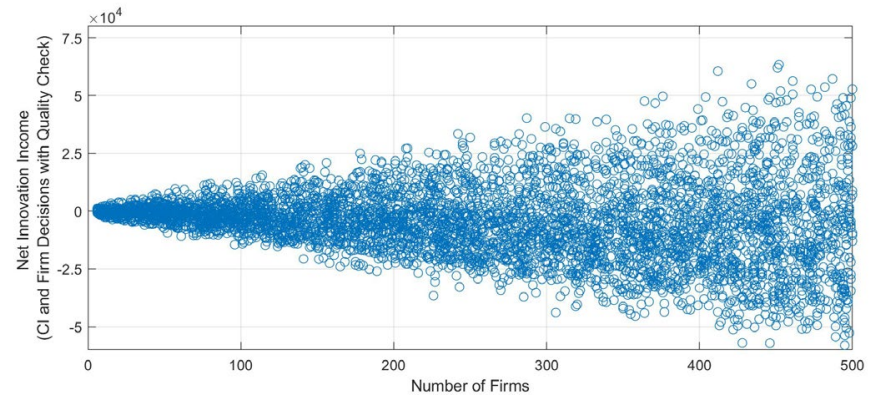

Figure 7: Star architecture, firms implementing innovation based on the quality of its own managers and $\mathrm{Cl}$ managers VS number of firms (equation 5).

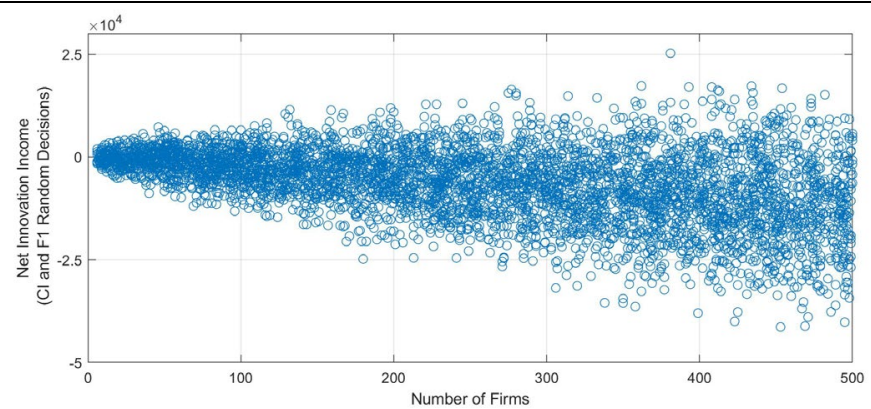

Figure 8: Star architecture, random collaborative decision between $\mathrm{Cl}$ managers and firms' managers VS number of firms (equation 7).

This indicates, as previously reported (Will et al 2019) that there is little difference between qualified and non-qualified managers in environments with many bad innovations. It also implies there could be scalability issues in the "star" model when expanding the STP, if there is not a concomitant increase in the decision-making quality in the $\mathrm{Cl}$. 


\subsection{Closed Network (Strongly Connected: Adhocracy and Ambidextrous)}

In this situation (Table 1, numbers 4 and 5 ) decision are made by $\mathrm{F}$ managers (especially by neighbouring firms in the architecture, representing two networked inhabitants making decisions collaboratively) with and without the $\mathrm{Cl}$, and thus the range of alternatives are:

i. A decision is made jointly between two $\mathrm{F}$ managers, where the quality of both $\mathrm{F}$ managers is controlled for (table 1 , number 1 , figure 11 ).

ii. A random decision is made by two $\mathrm{F}$ managers (table 1 , number 1 , figure 12 ).

iii. A random decision is made by $\mathrm{Cl}$ managers together with two neighbouring $\mathrm{F}$ managers (table 1 , number 5 , figure 10 ).

iv. A decision is made between two firms collaboratively with $\mathrm{Cl}$ managers with quality checks (table 1 , number 5 , figure 9 ).

Results are presented in table 7 which shows that in the worst cases situations, the values for the minimum net innovation values (the column named "min" in table 7) are approximately similar, for example the difference between decisions made by qualified $F$ managers (two firms), and non-qualified $\mathrm{F}$ managers (two firms), is not very high, around 10,000. Conversely the difference between ambidextrous organisation with qualified managers and random decision makers is around 5,000, indicating clearly that in the worstcase situation, more hierarchies will reduce the difference between qualified "good" managers and random decision makers.

Moving on from the worst-case situations there is a perhaps unsurprising gain from having qualified $\mathrm{F}$ managers and $\mathrm{Cl}$ managers, even though the transaction costs will be doubled when $\mathrm{Cl}$ is involved together with $\mathrm{F}$ managers (with quality check) nevertheless it is under these conditions that the value gain is highest. This represents the "ambidextrous" situation (table 1, number 5 ) and would be the preferred situation during times of expansion and scaling up the STP not only because the higher quality of decision-making will better shape the selection and intake of new innovative firms, but also because it would spread the use of resources and help prevent over-straining the $\mathrm{Cl}$. In more detail; figures 9-12 show the negative impact of growing the STP (this effect is due to the increasing transaction costs) however this negative tendency diminishes when quality control is added (figures 9 and 11).

Table 7 Descriptive Statistics Strongly-Connected architecture

\begin{tabular}{|l|l|l|l|l|l|}
\hline & N & Min & Max & Mean & STD \\
\hline Check by Two Firms (with quality control) & $5,000.00$ & $-46,757.00$ & $28,682.00$ & $-4,684.05$ & $10,091.34$ \\
\hline $\begin{array}{l}\text { Check by Two Firms and Cl (with quality } \\
\text { control) }\end{array}$ & $5,000.00$ & $-80,394.00$ & $54,878.00$ & $-11,835.29$ & $17,305.20$ \\
\hline $\begin{array}{l}\text { Check by Two Firms (without quality control) } \\
\text { C. }\end{array}$ & $5,000.00$ & $-59,252.00$ & $14,974.00$ & $-12,584.96$ & $11,877.17$ \\
\hline
\end{tabular}




\begin{tabular}{|l|l|l|l|l|l|}
\hline Random Decision by Two Firms and Cl & $5,000.00$ & $-84,959.00$ & $13,495.00$ & $-18,768.45$ & $16,767.01$ \\
\hline
\end{tabular}

$\mathrm{N}$ is number of simulation iteration, Min is the minimum net innovation measured as MU, Max is the maximum net innovation measured as $\mathrm{MU}$, and mean is the mean net innovation measured as $\mathrm{MU}$

Table 7 leads to our current working hypothesis; that during an initial stage, the $\mathrm{Cl}$ of start-up STPs must choose very innovative new inhabitants both to build the STP and to replace "churned" inhabitants. Mistakes in this stage incur modest costs. Ideally, this innovative base attracts larger firms and the managers of these larger firms can help the $\mathrm{Cl}$ to make correct decisions. If the STP cannot attract larger firms with experienced management, then the $\mathrm{Cl}$ will continue alone but, especially under conditions of growth and expansion, the cost of poor decisions will increase until eventual market failure ensues. Future research could investigate this hypothesis using panel data in STPs a various stages of development. 


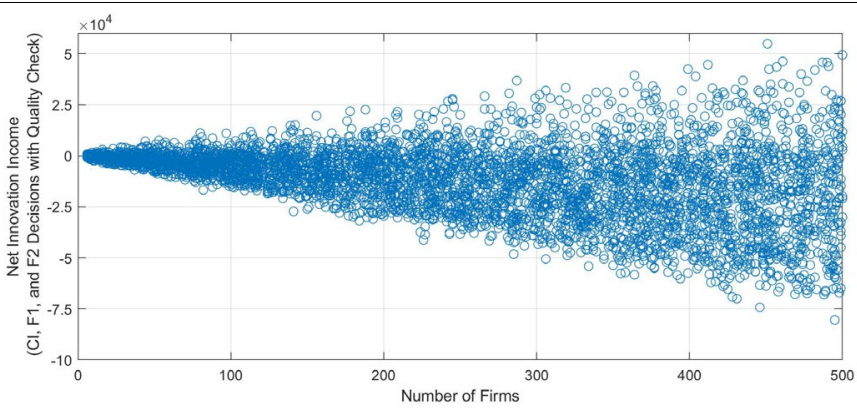

Figure 9: Ambidextrous Organisation, (F1, F2, and Cl) collaborative decision making with quality check VS number of firms (equation 9).

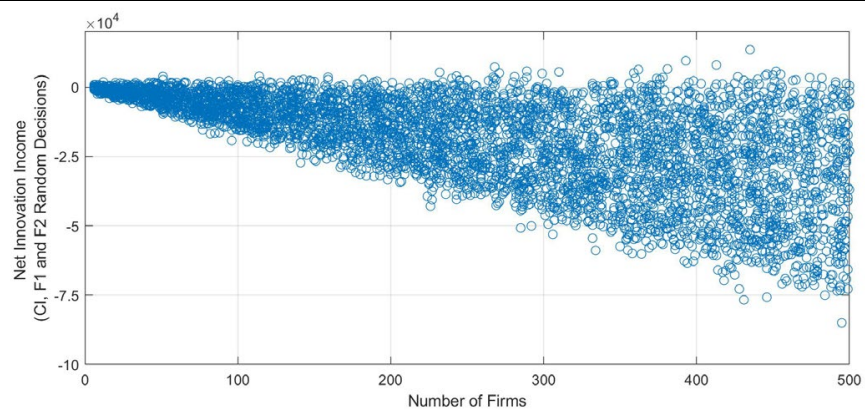

Figure 10: Ambidextrous Organisation, Random collaborative decision by (F1,F2, and CI) VS number of firms (equation 11).

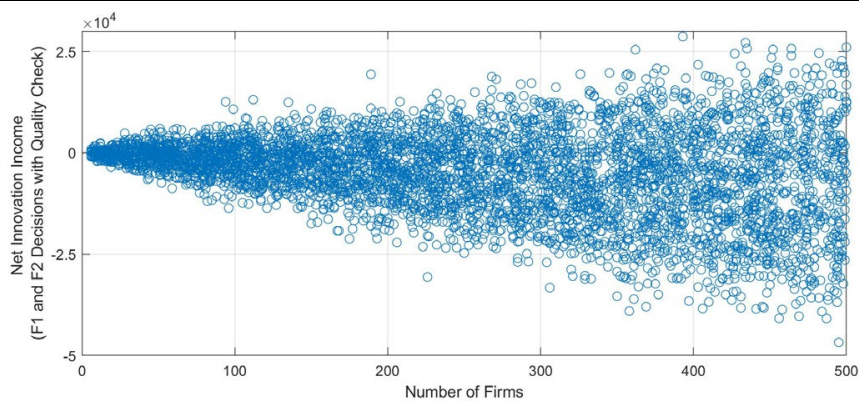

Figure 11: Ambidextrous Organisation, Collaborative decisions of (F1 and F2) with quality check VS number of firms (equation 8).

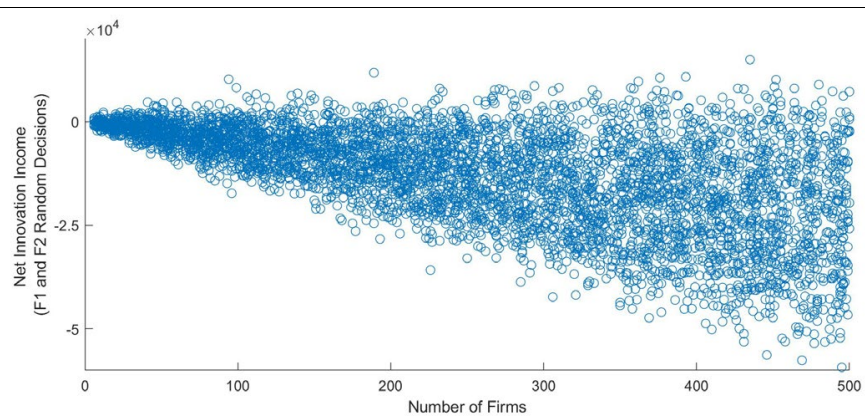

Figure 12: Ambidextrous Organisation, Collaborative random decisions of (F1 and F2) VS number of firms (equation 10). 


\subsection{Comparing Different Cluster Architectures}

Sections 3.1 - 3.3 discussed simulation results obtained by using different STP architectures under different decision-making conditions and best-case results are shown in table 8.

Table 8 Best Cases in all three architectures

\begin{tabular}{|c|c|l|l|l|l|}
\hline Architecture & Best Case & $\begin{array}{l}\text { Optimal } \\
\text { NOFs }\end{array}$ & $\begin{array}{l}\text { Optimal } \\
\text { Check Cost }\end{array}$ & $\begin{array}{l}\text { Optimal Average } \\
\text { Innovation } \\
\text { Income }\end{array}$ & $\begin{array}{l}\text { Net } \\
\text { Innovation }\end{array}$ \\
\hline Open Network & $\begin{array}{c}\text { Checked by Firm } \\
\text { with Quality } \\
\text { Control }\end{array}$ & 314.00 & 5.16 & 49.12 & $53,329.00$ \\
\hline Star architecture & $\begin{array}{c}\text { Check by Cl (with } \\
\text { quality control) }\end{array}$ & 482.00 & 1.48 & 33.41 & $132,316.00$ \\
\hline $\begin{array}{c}\text { Strongly } \\
\text { Connected } \\
\text { architecture }\end{array}$ & $\begin{array}{c}\text { Check by Two } \\
\text { Firms and Cl (with } \\
\text { quality control) }\end{array}$ & 451.00 & 2.03 & 36.96 & $54,878.00$ \\
\hline
\end{tabular}

NOF is Number of Firms

Table 8 presents the best cases in all the three different STP structures combined with the optimal number of firms, innovation income and check cost. It shows that the best outcomes occur when there is a quality check at either $\mathrm{F}$ or $\mathrm{Cl}$ level. Table 8 indicates that the star architecture structure is the best for achieving the highest return on incoming innovations, which is because of lower costs, i.e. a lower average innovation can achieve higher returns when decisions are centralized, although this may break down when the STP becomes significantly larger and, in agreement with the results of Al-kfairy et al (2019a) the strongly connected architecture model would be advantageous at this point.

A comparison of different cluster architectures under worst-case conditions is shown in table 9. This confirms that all worst-case situations occur when decisions are randomly made, and average income is quite low. The most damaging situation is encountered when innovations of low average value encounter an open (market) network architecture, which allows harmful innovations to proliferate without any embargo from the $\mathrm{Cl}$. Overall in the two other architectures the least-worst case is when innovation approval is happening at $\mathrm{F}$ level with qualified $\mathrm{F}$ managers and the worst-worst case when random decisions are made at the three levels (two $\mathrm{F}$ and $\mathrm{Cl}$ ), which is due to increased decision costs.

Table9: Worst Cases in Three Topologies

\begin{tabular}{|c|c|c|c|c|c|}
\hline Architecture & $\begin{array}{l}\text { Worst } \\
\text { Case }\end{array}$ & NOFs & Check Cost & Average Innovation Income & Net Innovation \\
\hline Open Network & $\begin{array}{l}\text { Random } \\
\text { Decision by } \\
\text { Firm }\end{array}$ & 350.00 & 35.20 & -116.57 & $-46,945.00$ \\
\hline $\begin{array}{l}\text { Star } \\
\text { architecture }\end{array}$ & $\begin{array}{l}\text { Random } \\
\text { Decision by } \\
\mathrm{Cl} \text { and Firm }\end{array}$ & 495.00 & 49.86 & -0.53 & $-64,590.00$ \\
\hline $\begin{array}{l}\text { Strongly } \\
\text { Connected } \\
\text { architecture }\end{array}$ & $\begin{array}{l}\text { Random } \\
\text { Decision by } \\
\text { Two Firms } \\
\text { and } \mathrm{Cl} \\
\end{array}$ & 495.00 & 49.86 & -0.53 & $-84,959.00$ \\
\hline
\end{tabular}

NOF is Number of Firms 


\section{Discussion}

This study complements previous studies focused on the role of networking in innovation development and knowledge spill-over (Cowan et al., 2007; Bathelt et al., 2004; Bell, 2005; Zhang et al., 2017), and studies on the role of Cl management e.g. (Ruiz et al., 2017; Klofsten et al., 2015; Sotarauta, 2010). However, as Nobel laureate Joseph Stiglitz points out, it is organizational architecture via decision-making that determines organizational profitability (e.g. Sah and Stiglitz, 1985). Thus, we go further by adding the dimension of organizational architecture into the debate, as well as exploring the quality of decision-makers at both $\mathrm{F}$ and $\mathrm{Cl}$ levels under regimes that include differing innovation environments.

Three different types of architectures: open (market), star (hierarchy), and closed strong (adhocracy, ambidextrous) architectures (see Cowan et al., 2007) were investigated and the results are broadly in agreement with previous studies. An open (market) model may for example include property-related services like the provision of infrastructure and most commonly utilized services (Salvador, 2011) encompassing conference and meeting rooms, restaurant and cafeteria, as well as more specialised facilities e.g. biowaste incinerator and chemical storage, where appropriate (Rowe, 2014). In this "top-down" structure barriers to entry are low, poor-fit firms can inhabit the STP and "bad" innovations can abound unchecked. Furthermore, the decentralised nature of decision-making in this architecture increases transaction costs. This situation may benefit from establishing a $\mathrm{Cl}$ with a clear vision for the future direction for the STP.

The star (hierarchy) and closed strong (adhocracy, ambidextrous) models both contain a strong $\mathrm{Cl}$ : The results presented here underline the crucial role played by the $\mathrm{Cl}$ in sustaining and developing an STP at the start-up stage and into early maturity. However, where this study differs from others is that the results presented here indicate that achieving a mature successful STP is not by a simple linear progression from earlier forms, rather they are different developmental trajectories that are pre-determined early on by the form of corporate organizational architecture chosen.

Clearly one starting point could be a costly large project, probably state-supported and, especially if large firms can be persuaded to participate, then a closed strong model may predominate and be successful. However, as Ernst and Young (2017) point out, this is a risky strategy because of many unknowns including that the size of the catchment area, in terms of potential inhabitants, is a large research gap, as are other important but unknown factors e.g. what are acceptable churn rates amongst inhabitants?

Another situation is a new small start-up STP containing small and micro-firms, and in this case the star (hierarchy) architecture is most suitable in early stages due to low transaction costs (Al-kfairy 2019a). Under certain circumstances this model can progress to an ambidextrous model, but star hierarchy should be retained in environments where the catchment is modest and high growth cannot be expected (table 7). Although these analyses support the views of (Chen et al., 2006; Albahari, 2015; Albahari et al., 2016) in that the quality of the $\mathrm{Cl}$ management team can be positively related to STP performance, the results underline that $\mathrm{a} \mathrm{Cl}$ is also of benefit where the quality of $\mathrm{Cl}$ decision-making is poor and the environment has relatively few suitable innovations or many poor-fit potential inhabitants, indeed table 2 shows a precarious situation where losses can be incurred even in steady-state, so the $\mathrm{Cl}$ in star hierarchy could be especially important in a situation where the STP is a startup and the on-cluster firms are also inexperienced start-ups.

In an analysis of a large mature STP, Al-kfairy et al. (2019b) observed that part of the STP demographic consists of micro-firms and many of these leave the STP after 4-5 years, and also a tendency for firms achieving a size of 100-120 employees to leave after 15-17 years, so 
STPs do indeed need to continually choose new inhabitants both for corporate performance but also - more importantly - to refresh the innovation base of the whole cluster and avoid "lock in" with old technology. Choosing new innovative inhabitants is inherently risky. The results presented show that concepts of "business ambidexterity" (see Benner and Tushman, 2003; Benner and Tushman, 2015; and O'Reilly III and Tushman, 2013), can be extended to clusters of firms, in this case STPs. However, there are unexpected differences between STPS and single organizations: Will et al. (2019) showed that for spreading innovations inside a single organization, multiple layers of $\mathrm{F}$ managers making decisions at close to coin-flipping (50:50) efficiency were still beneficial because at each decision round, moving up the hierarchy, $50 \%$ of expensive "bad" innovations were removed. In contrast, in the STP case, increasing the number of hierarchies showed a negative impact even when decision-making was good at both $\mathrm{Cl}$ and $\mathrm{F}$ levels, and this is due to increased transaction costs negating the advantage gained. Put simply, a firm co-locating to an STP entails a larger slice of costs than departmental decisions inside a firm. Ambidexterity, however, still has a place as the STP develops and strong inter-firm connections are formed, whereupon ambidextrous decisionmaking can be shared between the $\mathrm{Cl}$ and others, and this has a knock-on effect that the $\mathrm{Cl}$ can remain compact and cost-competitive as the STP reaches full maturity. To reach this outcome the $\mathrm{Cl}$ can include those managers at $\mathrm{F}$ level who are experienced and skilful decision-makers and this, in turn, underlines the importance of STPs of attracting large firms. Start-up STPs are ideally filled with innovative small firms and this situation (at an appropriate stage) can attract larger firms that do not want to miss out on these new innovations (perhaps by acquiring the aforesaid small innovative firms) and future research can investigate this using e.g. panel data from STPs in these early stages. Managers in the $\mathrm{Cl}$ have their routine tasks to do and may well not be aware of latest technologies and specialised market trends. Larger firms can contribute experienced $\mathrm{F}$ managers (presumably technically qualified and forward-thinking) who can co-operate with the $\mathrm{Cl}$ in making decisions. The tipping point is where the benefits from improved decision-making intersect with or exceed the increased transaction costs and consequently at this stage the structure of the STP moves to a growthoriented form; a strong ambidextrous architecture with a $\mathrm{Cl}$ at the centre encouraging valuable networking (Mellor, 2014b). The results presented here indicate however that the most valuable ratio includes the $\mathrm{Cl}$ and only any two of the larger firms; including more will drive the transaction costs up exponentially.

In conclusion, the timing of the transition from the star architecture to ambidextrous will be fraught, and from the overview presented in the introduction to this paper, only one in five STPs will achieve this situation. Those not able to do so can survive longest with a strong $\mathrm{Cl}$ star hierarchy, because this should enable them to avoid $50 \%$ of harmful innovations.

\section{References}

Albahari, A. (2015) '10 Science and Technology Parks: does one size fit all?' In J. T. Miao, P. Benneworth, and N. A. Phelps (Eds.) Making 21st century knowledge complexes: technopoles of the world revisited, pp. 191-207. London: Routledge.

Albahari, A., Barge-Gil, A., Pérez-Canto, S. and Modrego, A.(2018) 'The influence of science and technology park characteristics on firms' innovation results', Papers in regional science, Vol. 97 No.2, pp.253279.

Al-Kfairy, M., Khaddaj, S. and Mellor, R.B. (2017) 'Variables affecting high-tech cluster innovation: a statistical approach', In 7th International Conference on Law, Business, Marketing and Corporate Social Responsibilities, [online] London: HEAIG. Available at: http://heaig.org/images/proceedings_pdf/H12175121.pdf. 
Al-kfairy, M., Khaddaj, S. and Mellor, R. B. (2018) 'A Longitudinal Study of Corporate Benefits Accrued by Firms Inhabiting a Mature Science Park'. In: Proceeding of the $19^{\text {th }}$ European Conference on Knowledge Management. University of Padua, Italy. 6-7 September 2018. Vol. 1, PP. 76-84.

Al-kfairy, M., Khaddaj, S. and Mellor, R. B. (2019a) 'Computer modelling reveals the optimal development for the organisational structure of business clusters', International Journal of Knowledge-Based Development, 10 (3), 249-275.

Al-kfairy, M., Khaddaj, S. and Mellor, R. B. (2019b) 'Computer modelling and identification of factors important for the success of business clusters', International Journal of Knowledge-Based Development, (in press)

Bathelt, H., Malmberg, A. and Maskell, P. (2004) 'Clusters and knowledge: local buzz, global pipelines and the process of knowledge creation', Progress in Human Geography, Vol. 28 No.1, pp. 31-56.

Bell, G.G. (2005) 'Clusters, networks, and firm innovativeness', Strategic Management Journal, Vol. 26 No.3, pp. 287-295.

Benner, M.J., and Tushman, M. L. (2003)'Exploitation, Exploration, and Process Management: The Productivity Dilemma Revisited', Academy of Management Review, Vol. 28, No. 2, pp. 238-256.

Benner, M.J., and Tushman, M. L. (2015)'Reflections on the 2013 Decade Award - "Exploitation, Exploration, and Process Management: The Productivity Dilemma Revisited" Ten Years Later', Academy of Management Review, Vol. 40, NO. 4, pp. 497-518.

Breschi, S. and Malerba, F. (2001) 'The Geography of Innovation and Economic Clustering: Some Introductory Notes', Industrial and Corporate Change, Vol. 10 No.4, pp. 817-833.

Casanueva, C., Castro, I. and Galan, J.L. (2013) 'Informational networks and innovation in mature industrial clusters', Journal of Business Research, Vol. 66 No.5, pp. 603.

Chang, M. and Harrington, J.E. (2000) 'Centralization vs. decentralization in a multi-unit organization: A computational model of a retail chain as a multi-agent adaptive system', Management Science, Vol. 46 No.11, pp. 1427-1440.

Chib, S. and Greenberg, E. (1996) 'Markov chain Monte Carlo simulation methods in econometrics', Econometric Theory, Vol. 12 No.3, pp. 409-431.

Chen, C.-J., Wu, H.-L., \& Lin, B.-W. (2006) 'Evaluating the development of high-tech industries: Taiwan's science park', Technological Forecasting and Social Change, Vol. 73 No.4, pp.452-465.

Chyi, Y., Lai, Y. and Liu, W. (2012) 'Knowledge spillovers and firm performance in the high-technology industrial cluster', Research Policy, Vol. 41 No.3, pp. 556-564.

Cojocaru, A. and lonescu, S. (2016) 'The Advantages of Business Clusters', FAIMA Business \& Management Journal, Vol. 4 No.2, pp. 31-47.

Cowan, R., Jonard, N. and Zimmermann, J. (2007) 'Bilateral collaboration and the emergence of innovation networks', Management Science, Vol. 53 No.7, pp. 1051-1067.

Davis, J.P., Eisenhardt, K.M. and Bingham, C.B. (2009) 'Optimal structure, market dynamism, and the strategy of simple rules', Administrative Science Quarterly, Vol. 54 No.3, pp. 413-452.

Davis, J.P., Eisenhardt, K.M. and Bingham, C.B. (2007) 'Developing theory through simulation methods', Academy of Management Review, Vol. 32 No.2, pp. 480-499.

DeCanio, S.J., Dibble, C. and Amir-Atefi, K. (2000) 'The importance of organizational structure for the adoption of innovations', Management Science, Vol. 46 No.10, pp. 1285-1299.

Dettwiler, P., Lindelöf, P. and Löfsten, H. (2006) 'Utility of location: A comparative survey between small new technology-based firms located on and off Science Parks-Implications for facilities management', Technovation, Vol. 26 No.4, pp. 506-517.

Diez-Vial, I. and Fernández-Olmos, M. (2017) 'The effect of science and technology parks on a firm's performance: a dynamic approach over time', Journal of Evolutionary Economics, Vol. 27 No.3, pp. 413-434.

Díez-Vial, I and Montoro-Sánchez, A. (2016) 'How knowledge links with universities may foster innovation: The case of a science park', Technovation, Vol. 50, pp 41-52 
Eisingerich, A.B., Bell, S.J. and Tracey, P. (2010) 'How can clusters sustain performance? The role of network strength, network openness, and environmental uncertainty', Research Policy, Vol. 39 No.2, pp. 239-253.

Ernst \& Young (2017) 'UK SBS PS17086. Catapult Network Review.' [Online ] available at https://assets.publishing.service.gov.uk/government/uploads/system/uploads/attachment_data/file /662509/Catapult_Review_-_Publishable_Version_of_EY_Report_1_.pdf

Ethiraj, S.K. and Levinthal, D. (2004) 'Modularity and innovation in complex systems', Management Science, Vol. 50 No. 2, pp. 159-173.

Etzkowitz, H. and Leydesdorff, L. (2000) 'The dynamics of innovation: from National Systems and "Mode 2" to a Triple Helix of university-industry-government relations', Research Policy, Vol.29 No.2, pp. 109123.

Field, A. (2013) Discovering statistics using IBM SPSS statistics. sage.

García-Manjón, J.V. and Romero-Merino, M.E. (2012) 'Research, development, and firm growth. Empirical evidence from European top R\&D spending firms', Research Policy, Vol.41 No.6, pp. 1084-1092.

Gilbert, N., Ahrweiler, P. and Pyka, A. (2007) 'Learning in innovation networks: Some simulation experiments', Physica A: Statistical Mechanics and its Applications, Vol.378 No.1, pp. 100-109.

Guan, J. and Chen, K. (2010) 'Measuring the innovation production process: A cross-region empirical study of China's high-tech innovations', Technovation, Vol.30 No.5, pp. 348-358.

Henriques, I.C., Sobreiro, V.A. and Kimura, H. (2018) 'Science and technology park: Future challenges', Technology in Society, Vol.53, pp.144-160.

Hommen, L., Doloreux, D. and Larsson, E. (2006) 'Emergence and Growth of Mjärdevi Science Park in Linköping, Sweden 1', European Planning Studies, Vol.14 No.10, pp. 1331-1361.

lammarino, S. and McCann, P. (2006) 'The structure and evolution of industrial clusters: Transactions, technology and knowledge spillovers', Research Policy, Vol.35 No.7, pp. 1018-1036.

IASP (2016) IASP. Available at: http://www.iasp.ws/ (Accessed 30 March 2016).

Kelly, T.J.C. and Firestone, R.S. (2016) How tech hubs are helping to drive economic growth in Africa. World Development Report background papers. Washington, D.C.: World Bank Group.

Khanna, R., Guler, I. and Nerkar, A. (2016) 'Fail often, fail big, and fail fast? Learning from small failures and R\&D performance in the pharmaceutical industry', Academy of Management Journal, Vol.59 No.2, pp. 436-459.

Klofsten, M. et al. (2015) 'Success factors in cluster initiative management: mapping out the'big five", Industry and Higher Education, Vol.29 No.1, pp. 65-77.

Klofsten, M., Jones-Evans, D. and Schärberg, C. (1999) 'Growing the Linköping Technopole-A Longitudinal Study of Triple Helix Development in Sweden', The Journal of Technology Transfer, Vol.24 No.2, pp. 125-138.

Koçak, Ö. and Can, Ö. (2013) 'Determinants of inter-firm networks among tenants of science technology parks', Industrial and Corporate Change, Vol.23 No.2, pp.467-492.

Leydesdorff, L. and Etzkowitz, H. (2003) 'Can 'the public'be considered as a fourth helix in universityindustry-government relations? Report on the Fourth Triple Helix Conference, 2002', Science and Public Policy, Vol.30 No.1, pp. 55-61.

Lönnqvist, A. and Laihonen, H. (2017) 'Management of knowledge-intensive organisations: what do we know after 20 years of research?', Int. J. Knowledge-Based Development, Vol. 8, No. 2, pp.154-167.

Markusen, A. (1996) 'Sticky Places in Slippery Space: A Typology of Industrial Districts', Economic Geography, Vol.72 No.3, pp. 293-313.

Mellor, R. B. (2003): Innovation management. Denmark, Forlaget Globe. 94p. ISBN 8779001963

Mellor, R.B. (2011) Knowledge management and information systems : strategies for growing organizations. Basingstoke: Palgrave Macmillan.

Mellor, R.B. (2014a) 'Knowledge valley theory', International Journal of Knowledge-Based Development, Vol.5 No.1, pp. 5-16. 
Mellor, R. B. (2014b): The use of knowledge assets. Modelling the potential effect of adding innovators to low-innovation and high-innovation SMEs. International Journal of Knowledge-Based Development, 5(4), 367-380.

Mellor, R. B. (2015) 'Computer-Modelling the Innovation-Based Theory of the Firm', In: 16th European Conference on Knowledge Management ECKM 2015; 3 - 4 Sep 2015, Udine, Italy pp 532-538.

Mellor, R. B. (2018) 'Big data modelling the knowledge economy'. International Journal of KnowledgeBased Development, Vol.9 No.3, pp. 206-220.

Mellor, R.B. (2019) 'Entrepreneurship'. In; Mellor, R.B. (ed) Management for Scientists. Emerald, UK.

Mudambi, R. and Swift, T. (2011) 'Proactive R\&D management and firm growth: a punctuated equilibrium model', Research Policy, Vol.40 No.3, pp. 429-440.

Navimipour, N.J., Milani, F.S. and Hossenzadeh, M. (2018) 'A model for examining the role of effective factors on the performance of organizations', Technology in Society, Vol. 55, pp.166-174.

O'Reilly III, A., and Tushman ,L. (2013). 'Organizational Ambidexterity: Past, Present, and Future', Academy of Management Perspectives, Vol. 27, No. 4, pp. 324-338.

Pitelis, C. (2012) 'Clusters, entrepreneurial ecosystem co- creation, and appropriability: a conceptual framework', Industrial and Corporate Change, Vol.21 No.6, pp. 1359-1388.

Porter, M.E. (2000) 'Location, competition, and economic development: Local clusters in a global economy', Economic Development Quarterly, Vol.14 No.1, pp. 15-34.

Porter, M. (2003) 'The Economic Performance of Regions', Regional Studies, Vol.37 No.6-7, pp. 549-578.

Porter, M.E. (1998) The competitive advantage of nations. New ed, with a new introduction.. edn. Basingstoke: Basingstoke : Macmillan.

Pugh, R., MacKenzie, N.G. and Jones-Evans, D. (2018) 'From 'Techniums' to 'emptiums': the failure of a flagship innovation policy in Wales', Regional Studies, Vol.52 No.7, pp. 1009-1020.

Robinson, S. (2014) Simulation: the practice of model development and use. Palgrave Macmillan.

Rowe, D. (2014). Setting up, managing and evaluating EU science and technology parks-An advice and guidance report on good practice. Brussels: European Commission, Directorate-General for Regional and Urban Policy.

Ruiz, M.S. et al. (2017) 'Proposal of a theoretical model for the implementation and scalability of science parks: a case study', RAI Revista de Administração e Inovação, Vol.14 No.1, pp. 2-15.

Sah, R. K., and Stiglitz , J. E.(1985). 'Human Fallibility and Economic Organization', The American Economic Review, Vol. 75, No. 2, pp. 292-297.

Salvador, E. (2011) 'Are science parks and incubators good "brand names" for spin-offs? The case study of Turin', The Journal of Technology Transfer, Vol.36 No.2, 203-232.

Saxenian, A. (1994) Regional Advantage: Culture and Competition in Silicon Valley and Route 128. 1st edn. Cambridge, MA: Harvard University Press.

Shahzad, F., Xiu, G. and Shahbaz, M. (2017) 'Organizational culture and innovation performance in Pakistan's software industry', Technology in Society, Vol.51, pp. 66-73.

Skokan, K., Poledníková, E. and Stanícková, M. (2012) 'Establishment and Growth of Business Clusters with Public Aid', Journal of Competitiveness, Vol.4 No.3.

Sotarauta, M. (2010) 'Regional development and regional networks: The role of regional development officers in Finland', European Urban and Regional Studies, Vol.17 No.4, pp. 387-400.

Squicciarini, M. (2008) 'Science Parks' tenants versus out-of-Park firms: who innovates more? A duration model', The Journal of Technology Transfer, Vol.33 No.1, pp. 45-71.

Stevens, G.A. and Burley, J. (1997) '3,000 raw ideas= 1 commercial success!', Research-Technology Management, Vol.40 No.3, pp. 16-27.

Tallman, S., Jenkins, M., Henry, N. and Pinch, S. (2004) 'Knowledge, clusters, and competitive advantage', Academy of management review, Vol.29 No.2, pp.258-271.

Ting Helena Chiu, Y. (2008) 'How network competence and network location influence innovation performance', Journal of Business \& Industrial Marketing, Vol.24 No.1, pp. 46-55.

Van der Panne, G., Van Beers, C. and Kleinknecht, A. (2003) 'Success and failure of innovation: a literature review', International Journal of Innovation Management, Vol.7 No.03, pp. 309-338. 
Wadhwa, V. (2013) 'Silicon Valley Can't Be Copied', Technology Review, Vol.116 No.5, pp. 87-88.

Wallsten, S. (2004a) 'The role of government in regional technology development: The effects of public venture capital and science parks',In. Building High-Tech Clusters: Silicon Valley and Beyond.Cambridge University Press, Cambridge, pp. 229-279.

Wallsten, S. (2004) 'High-tech cluster bombs: why successful technology hubs are the exception, not the rule', American Enterprise Institute. On the issues.

Will, M. G., Al-Kfairy, M. and Mellor, R. B. (2019) 'How organizational structure transforms risky innovations into performance : a computer simulation', Simulation Modelling Practice and Theory, Vol.94, pp. 264-285. ISSN (print) 1569-190X

Yang, Z., Gao, S. and Yang, J. (2016) 'Emergence of biotechnology clusters: How prior structure affects formation of technology connections in Boston and San Diego from 1979 to 2006', The Journal of High Technology Management Research, Vol.27 No.1, pp. 21-36.

Zhang, G., Duan, H. and Zhou, J. (2017) 'Network stability, connectivity and innovation output', Technological Forecasting and Social Change, Vol.114, pp.339-349.

Zhao, W., Watanabe, C. and Griffy-Brown, C. (2009) 'Competitive advantage in an industry cluster: The case of Dalian Software Park in China', Technology in Society, Vol.31 No.2, pp. 139-149. 